\title{
Nurses' attitudes facing the family involvment in caring for people with mental disorder
}

\author{
Atitudes de enfermeiros frente ao envolvimento da família nos cuidados à pessoa com transtorno mental \\ Actitudes de enfermeras frente a la participación familiar en el cuidado de personas con trastorno mental
}

\section{Maria do Perpétuo Socorro de Sousa Nóbrega ' ORCID: 0000-0002-4974-0611}

Carla Sílvia Neves da Nova Fernandes " ORCID: 0000-0001-7251-5829

Sonia Regina Zerbetto "II ORCID: 0000-0002-2522-1948

Francisco Miguel Correia Sampaio'v ORCID: 0000-0002-9245-256X

Estela Duarte' ORCID: 0000-0003-3859-4599

Suellen Cristina da Silva Chaves ORCID: 0000-0003-3234-9752

Wanderson Carneiro Moreira ORCID: 0000-0003-2474-1949

'Universidade de São Paulo. São Paulo, São Paulo, Brazil. "Escola Superior de Enfermagem do Porto. Porto, Portugal I" Universidade Federal de São Carlos. São Carlos, São Paulo, Brazil "Universidade Fernando Pessoa. Porto, Portugal

How to cite this article: Nóbrega MPSS, Fernandes CSNN, Zerbetto SR, Sampaio FMC, Duarte E, Chaves SCS, et al. Nurses' attitudes facing the family involvment

in caring for people with mental disorder Rev Bras Enferm. 2020;73(Suppl 1):e20200041. doi: http://dx.doi.org/10.1590/0034-7167-2020-0041

\section{Corresponding author:}

Maria do Perpétuo Socorro de Sousa Nóbrega E-mail: perpetua.nobrega@usp.br

EDITOR IN CHIEF: Antonio José de Almeida Filho ASSOCIATE EDITOR: Alexandre Balsanelli

\section{ABSTRACT}

Objective: To characterize the attitudes of Primary Health Care nurses, regarding the involvement of the family in the care for people with Mental Disorder. Methods: Correlational study with 257 nurses from the city of São Paulo. The scale "Importance of Families in Nursing CareNurses' Attitudes" was used. For the analysis, descriptive and inferential statistics were used. Results: The scale scores were high, with a mean value of $82.1(\mathrm{SD}=8.4)$ favorable to the families' involvement, and are related to being a nurse in the Family Health Strategy $(p<0.001)$, having received education/training in family nursing $(p<0.005)$, the workload of 40 hours/ week $(p<0.005)$, working in the West, East and Center Regions $(p<0.005)$. Conclusion: Most nurses have positive attitudes towards the involvement of families, a relevant indicator for their inclusion in the health-mental care process.

Descriptors: Mental Disorders; Nurses; Family; Attitude of Health Personnel; Primary Health Care.

\section{RESUMO}

Objetivo: Caracterizar as atitudes dos enfermeiros, de Atenção Primária à Saúde, quanto ao envolvimento da família nos cuidados às pessoas com Transtorno Mental. Métodos: Estudo correlacional, com 257 enfermeiros do município de São Paulo. Utilizou-se a escala "Importância das Famílias nos Cuidados de Enfermagem-Atitudes dos Enfermeiros". A análise foi realizada com recurso de estatística descritiva e inferencial. Resultados: Os escores da escala foram elevados, com valor médio de $82,1(\mathrm{DP}=8,4)$ favoráveis ao envolvimento das famílias, e estão relacionadas a ser enfermeiro da Estratégia de Saúde da Família $(p<0,001)$, ter recebido conteúdos sobre enfermagem de família na formação/capacitação $(p<0,005)$, carga-horária de trabalho de $40 \mathrm{hs} / \mathrm{sem}(\mathrm{p}<0,005)$, atuar nas Regiões Oeste, Leste e Centro $(p<0,005)$. Conclusão: Os enfermeiros detêm, na sua maioria, atitudes positivas para com o envolvimento das famílias, indicador relevante para a integração destas no processo de cuidado em saúde-doença mental.

Descritores: Transtornos Mentais; Enfermeiros; Família; Atitude do Pessoal de Saúde; Atenção Primária à Saúde.

\section{RESUMEN}

Objetivo: caracterizar las actitudes de los enfermeros en Atención Primaria de Salud con respecto a la participación de la familia en la atención a las personas con Trastorno Mental. Métodos: estudio correlacional con 257 enfermeros de la ciudad de São Paulo. Se utilizó la escala "Importancia de la familia en los cuidados de enfermería: actitudes de las enfermeras". El análisis se realizó mediante estadística descriptiva e inferencial. Resultados: los puntajes de la escala fueron altos, con un valor promedio de 82.1 ( $\mathrm{DE}=8.4$ ) favorables a la participación de las familias, y están relacionados con ser un enfermero en la Estrategia de Salud Familiar $(p<0.001)$, haber recibido contenido sobre enfermería familiar en la educación/formación $(p<0.005)$, carga de trabajo de 40 horas/semana $(p<0.005)$ y trabajar en las regiones Oeste, Este y Centro $(p<0.005)$. Conclusión: la mayoría de los enfermeros tienen actitudes positivas hacia la participación de las familias, un indicador relevante para su integración en el proceso de atención de salud-enfermedad mental.

Descriptores: Trastornos Mentales; Enfermeros; Familia; Actitud del Personal de Salud; Atención Primaria de Salud.

Submission: 04-02-2020 Approval: 06-29-2020 


\section{INTRODUCTION}

Theoretical and practical evidence on the family's role on the well-being of its members, allows nurses to consider them as a unit to be cared for and inserted in practice, based on the systemic perspective ${ }^{(1)}$. The openness of health services regarding the inclusion of families in care has evolved in recent decades, but it is still focused on hospital environments and individual care. Also, this care is based on the biomedical, disease paradigm, and does not focus on the family as a client ${ }^{(2)}$.

It is known that family support and involvement increase the quality of care for people with mental disorders (MD), understood here as a complex manifestation, considering the social, economic, cultural and environmental aspects of living, for the person and family ${ }^{(3)}$. However, in the field of mental health $(\mathrm{MH})$, stress is pointed out in the relationship between these families and health care providers due to negative stereotypes imposed on the family, which contribute to feelings of shame and discrimination ${ }^{(4)}$, which results in overload and failure to recognize their support potential ${ }^{(1)}$.

By involving the families, the nurse cooperates so they find meaning for the experience of their suffering, build new meanings for the health-disease process, expand knowledge, and develop skills in the care scenario. Such actions help to improve the positive attitudes of other professionals in the field of $\mathrm{MH}^{(5)}$ and favor positive impacts on health indicators ${ }^{(6)}$. It is understood that attitudes are "the convictions and feelings that predispose our reactions to objects, people and events" and when considering that someone "is a bad person and has a bad personality", one can have attitudes of disgust and hostility towards this person ${ }^{(7)}$.

Families report feelings of marginalization and distancing from professional caregivers, expressed in negative behaviors that cause guilt for the family member's MD problems ${ }^{(4)}$. Thus, in to advance in the perspective of changes, it is essential to build a partnership between nurse-family, so the planning of nursing care for the person with MD is collaborative, to improve the relationships as a whole, which requires changes nurses' attitudes towards family involvement ${ }^{(2)}$.

In a literature review, primary health care nurses in Portugal showed supportive attitudes for the family of people with MD, and they believe that the decision to include them enhances their role as an enabling mediator in the care reorganization process ${ }^{(8)}$. In China, the attitudes of generalist nurses were less supportive concerning the importance of the family in nursing care, and aroused the perception, in families, that nurses are unable to offer the care that involves them. However, when they have inclusion attitudes, the quality of care provided improves. The authors also emphasize that the training of generalist nurses, and even of mental health specialists, is crucial so that they can approach the family to a care centered role ${ }^{(9)}$.

In Australia, a study, which analyzed the experiences of relatives of people with MD concerning their interactions and contributions in care, points out that nurses need to recognize the role and understand the experiences of families, to ensure an approach focused on care, since they are in a better condition to recognize changes in the patient's clinical status and cooperate in care planning ${ }^{(10)}$. Other authors point out that the family may feel deserted if left alone or not involved in the treatment of loved ones, with little opportunities to provide information and little power in decision-making, although the evidence refers that working with families is not only beneficial for short-term results, but can also achieve lasting improvements in the work and quality of life of people with $\mathrm{MD}^{(11)}$.

A study highlights that the $\mathrm{MH}$ guidelines, when suggesting some type of family involvement, state that their inclusion can help to prevent relapses and reduce hospitalizations, despite not having clearly defined what establishes the involvement of families in care and the best method to combine them ${ }^{(12)}$. In Sweden, it was found that professionals support the involvement of families, but to invite them they were less favorable, and that working in a primary care center and having competence in dealing with families are predictive factors for positive attitudes ${ }^{(13)}$.

In Brazil, back to the institutional days, due to the isolation that was imposed to the person with MD, families were excluded and blamed for the problems of the sick family member ${ }^{(14)}$. Thus, studies on the family's inclusion in the mental health care are recent, and focused on specialized spaces, from a perspective of more spectators than protagonists. Only with the redirection of the mental health policy, the family has been called to include and contribute to the deinstitutionalization process, which has been configured in the Psychosocial Care Network (RAPS), in the commitment of the Family Health Strategy (FHS) and in the figure of nurses who must embrace and include families of people with MD in care ${ }^{(15)}$.

Since, in a national literature review, no studies were found on the attitudes of nurses in Primary Health Care (PHC) concerning the inclusion of families in care, this study fills a knowledge gap that enables to strengthen $\mathrm{MH}$ in this scenario.

\section{OBJECTIVE}

To characterize the attitudes of Primary Health Care nurses regarding the involvement of the family in the care of people with Mental Disorder.

\section{METHODS}

\section{Ethical aspects}

Study approved by the Research Ethics Committee with Human Beings of a Public University and of the Health Department of São Paulo, according to Resolution 466/12 of the National Health Council.

\section{Study design}

This is a quantitative, descriptive-correlational, and crosssectional study. It is part of the multicenter study entitled "Attitudes in Primary Health Care", conducted between Portugal and Brazil.

\section{Setting}

Carried out in the city of São Paulo, in 69 Basic Health Units (BHU) with/without the FHS, from eight Health Districts (HD), of the six Regional Health Coordinators (RHC) of the city of São Paulo. The following HD participated: Microregion of Vila Maria/ Vila Guilherme, (North), Microregion Butantã (West), Ipiranga 
District, Jabaquara District and Vila Prudente District (Southeast), Guaianazes District (East), Campo Limpo (South) and Sé (Center). This study was reported according to the STROBE guidelines.

\section{Data source}

This was a Convenience sampling in which 257 nurses participated. As an inclusion criterion, work in $\mathrm{PHC}$ (regardless of the time of professional experience) in the service, management, and assistance. The exclusion criterion was to work exclusively in management.

\section{Data collection and organization}

Research carried out from April to August 2019, using a sociodemographic questionnaire (including age, sex, marital status, birthplace, religion, professional training, time of experience, time working in the unit, total weekly workload), also a labor questionnaire with questions about training and professional experiences with families of people with MD. The scale "Importance of Families in Nursing Care - Nurses' Attitudes" (IFNC-NA) was applied, with a Likert type response (four options), which allows the assessment of nurses' attitudes in their cognitive, affective and behavioral aspects ${ }^{(16)}$. The IFNC-NA was translated and validated for the Brazilian population ${ }^{(17)}$, and includes three subscales: family as a conversational partner and coping resource (12 items) - indicates the appreciation of family involvement in care, ranging from 12 to 48; family as a resource for nursing care (10 items) - demonstrates the strength points of the family that assist in the care, ranging from 10 to 40; and family as a burden (4 items) - expresses points of exhaustion that interfere with the inclusion of the family in care, ranging from 4 to 16.

The internal consistency of the IFNC-NA found in the present study, was $(=0,91)$. The value is higher than that found by the authors who validated it for the Brazilian population $(=0,81)^{(17)}$, which confirms the idea that it is a scale with very good internal consistency. The possible scores vary between 26 and 104, midpoint 65, mode 77, median 80 and Standard Deviation 8.4. For the evaluation of the result of the scale, the higher the score, the better the nurses' attitudes towards families. After contacting the BHU managers and explaining about the research, the instruments were sent. It is worth mentioning that continuous support was offered to nurses.

\section{Data analysis}

The IBM SPSS-25 was used. Nominal categorical variables were described and presented in frequency tables. For descriptive statistics, the mean and standard deviation (SD) were used. The Mann-Whitney test was applied to identify the distribution in the two samples, with a statistical significance of $p<0.05$ and a $95 \%$ confidence interval.

\section{RESULTS}

\section{Sociodemographic profile}

The sample $(n=257)$ is predominantly female; with a mean age of 36.3 years $(\mathrm{SD}=7.5)$, ranging from 23 to 65 years; graduated from a private institution (84\%); native of the Southeast region of the country (42.0\%); who works in only one job (88.7\%); Catholic (69.2\%). The most supportive attitudes, therefore more positive, were concerning the workload $(p=0.001)$, having received guidance on family nursing in undergraduate school and/or training $(p=0.004)$, working in certain RHC/D ( $p=0.001)$ and work in the FHS ( $p<0.001)$, Table 1.

Table 1 - Distribution of nursing professionals according to sociodemographic and work variables, Attitudes in Primary Health Care Research, São Paulo, Brazil, 2019

\begin{tabular}{|c|c|c|}
\hline Variable & n (\%) & $p$ value \\
\hline $\operatorname{Sex}(N=257)$ & & 0.121 \\
\hline Men & $43(17.20)$ & \\
\hline Women & $214(82.80)$ & \\
\hline Marital Status (N=257) & & 0.632 \\
\hline Single & $74(28.90)$ & \\
\hline Married & $178(69.20)$ & \\
\hline Widower/widow & $3(1.13)$ & \\
\hline Separated & $2(0.77)$ & \\
\hline Religion ( $N=253$ ) & & 0.236 \\
\hline Catholic & $122(44.70)$ & \\
\hline Evangelical & $71(27.20)$ & \\
\hline Other & $37(18.30)$ & \\
\hline None & $23(9.80)$ & \\
\hline $\mathrm{HD} / \mathrm{RHC} *(\mathrm{~N}=256)$ & & 0.001 \\
\hline North (Vila Maria/Guil.) & $70(26.10)$ & \\
\hline South (Campo Limpo) & $42(17.90)$ & \\
\hline West (Butantã) & $62(23.70)$ & \\
\hline East (Guaianases) & $16(5.80)$ & \\
\hline Southeast (Ipir./Prud.) & $56(23.00)$ & \\
\hline Center (Sé) & $19(3.50)$ & \\
\hline Degree $(N=257)$ & & 0.529 \\
\hline Bachelor & $214(83.10)$ & \\
\hline Especialization & $31(13.00)$ & \\
\hline Master & $10(3.10)$ & \\
\hline Doctorate & $2(0.80)$ & \\
\hline Time since graduation $(\mathrm{N}=257)$ & & 0.073 \\
\hline$<1$ year & $2(0.77)$ & \\
\hline 1 to 5 years & 78 (30.36) & \\
\hline 5 to 10 years & $101(39.29)$ & \\
\hline 10 to 20 years & $65(25.30)$ & \\
\hline$>20$ years & $11(4.28)$ & \\
\hline Time in the profession $(\mathrm{N}=257)$ & & 0.218 \\
\hline$<1$ year & $15(5.83)$ & \\
\hline 1 to 5 years & $65(41.76)$ & \\
\hline 5 to 10 years & $107(25.71)$ & \\
\hline 10 to 20 years & $33(12.34)$ & \\
\hline$>20$ years & $37(14.36)$ & \\
\hline Weekly hours ( $\mathrm{N}=257$ ) & & 0.001 \\
\hline $44 \mathrm{~h}$ & $23(8.95)$ & \\
\hline $40 \mathrm{~h}$ & $164(63.81)$ & \\
\hline $36 \mathrm{~h}$ & $31(12.06)$ & \\
\hline $30 \mathrm{~h}$ & $39(15.18)$ & \\
\hline Training on family nursing $(\mathrm{N}=200)$ & & 0.004 \\
\hline No & $25(9.72)$ & \\
\hline Yes & $175(68.09)$ & \\
\hline $\mathrm{FHS} *(\mathrm{~N}=257)$ & & $<0.001$ \\
\hline No & $83(21.90)$ & \\
\hline Yes & $174(78.10)$ & \\
\hline
\end{tabular}

\section{Nurses' attitudes towards families}

The sum of the IFNC-NA scores, with a range from 26 to 104 mean of 65 , enabled to obtain a global measure of the professional's characteristics, whose total mean was 82.1 with $\mathrm{SD}=8.4$, 
higher than the mean point, estimating that nurses have mostly positive attitudes regarding the involvement of families. In the subscale "Family: a conversational partner and coping resource", with a question like:"I debate with the family and invite you to actively participate in the care process", the average score was 38.5 (Min-12; Max- 48) with $\mathrm{SD}=4.6$. In the subscale "Family: as a resource for nursing care", which includes the question "I acquire a great valuable knowledge with families, which I can use at work", the average score was 31.9 (Min-10; Max-40) with SD=3.7. Finally, in the subscale "Family: as a burden", which includes the question: "The presence of family members makes me feell am being evaluated", the average score was 12.1 (Min-4; Max-16) and SD = 1.5, (Table 2).

Table 2 - "Importance of Families in Nursing Care - Nurses' Attitudes" (IFNC-NA) dimensions, Attitudes in Primary Health Care Research, São Paulo, Brazil, 2019

\begin{tabular}{lccc}
\hline Dimension & $\begin{array}{c}\mathbf{N}^{\circ} \text { of } \\
\text { items }\end{array}$ & $\begin{array}{c}\text { Mean } \\
\text { (SD) }\end{array}$ & Amplitude \\
\hline Total Scale & 26 & $82.1(8.4)$ & $40-101$ \\
Family as a conversational partner and & 12 & $38.5(4.6)$ & $13-48$ \\
coping resource & 10 & $31.9(3.7)$ & $14-40$ \\
Family as a resource for care & 4 & $12.1(1.5)$ & $8-16$ \\
Family as a burden & & & \\
\hline
\end{tabular}

\section{Nurses' attitude $\mathrm{x}$ performance scenario}

The average of the total score of the IFNC-NA and the HD were: North $(=77.0)$, Center $(=83.0)$, Southeast $(=80.0)$, South $(=82.0)$, East $(=83.0)$ and West (=83.0). Nurses from HD Butantã (West), Guaianazes (East) and Sé (Center) presented a mean of the total score of 83.0, respectively, therefore with slightly more positive attitudes concerning the North, South and Southeast ( $p=0.001)$, (Figure 1).

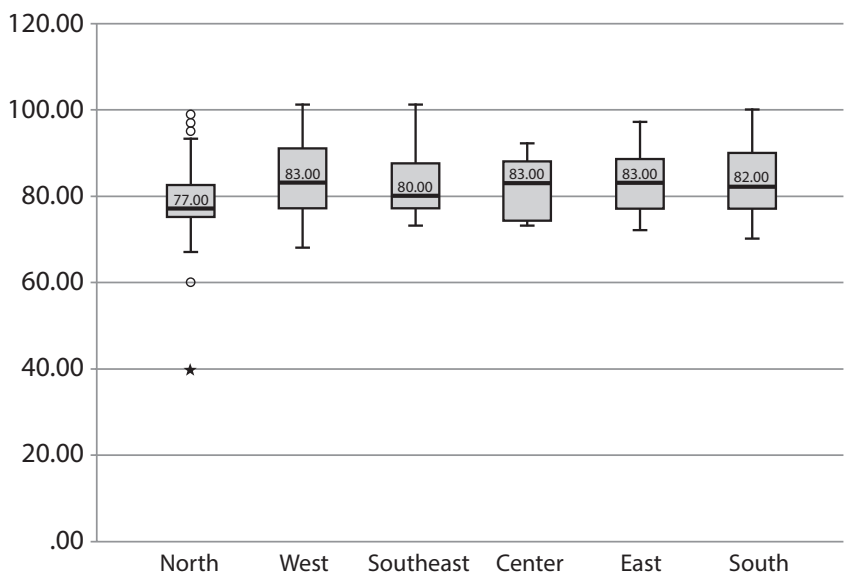

Figure 1 - Relationship of "Importance of Families in Nursing Care - Nurses' Attitudes" (IFNC-NA) and Health Districts/Regional Health Coordinators (RHC/HD), Attitudes in Primary Health Care Research, São Paulo, Brazil, 2019

\section{Nurses' attitudes $\mathrm{x}$ workload}

It worth noting that the attitudes of nurses who work a 40hour/week workload are more positive than those who have shorter workloads, both within the scope of the total IFNC-NA and in the three dimensions $(p<0.05)$, (Table 3$)$.
Table 3 - "Importance of Families in Nursing Care - Nurses' Attitudes" (IFNCNA) dimensions, workload, Attitudes in Primary Health Care Research, São Paulo, Brazil, 2019

\begin{tabular}{|c|c|c|c|c|c|c|c|c|}
\hline \multirow[b]{2}{*}{ Variable } & \multicolumn{2}{|r|}{$30 \mathrm{H}$} & \multicolumn{2}{|r|}{$36 \mathrm{H}$} & \multicolumn{2}{|c|}{$40 \mathrm{H}$} & \multicolumn{2}{|c|}{$44 \mathrm{H}$} \\
\hline & $\mathbf{n}$ & $\begin{array}{c}\text { Mean } \\
\text { (SD) }\end{array}$ & n & $\begin{array}{c}\text { Mean } \\
\text { (SD) }\end{array}$ & $\mathbf{n}$ & $\begin{array}{c}\text { Mean } \\
\text { (SD) }\end{array}$ & $\mathbf{n}$ & $\begin{array}{c}\text { Mean } \\
\text { (SD) }\end{array}$ \\
\hline IFNC-NA & 39 & $\begin{array}{c}78.21 \\
\#(10.20)\end{array}$ & 31 & $\begin{array}{c}87.96 \\
\#(6.33)\end{array}$ & 164 & $\begin{array}{c}83.48 \\
\#(7.88)\end{array}$ & 23 & $\begin{array}{c}82.17 \\
\#(8.66)\end{array}$ \\
\hline Coping & 39 & $\begin{array}{c}36.18 \\
\#(5.68)\end{array}$ & 31 & $\begin{array}{c}36.97 \\
\#(3.06)\end{array}$ & 164 & $\begin{array}{c}38.76 \\
\#(4.36)\end{array}$ & 23 & $\begin{array}{c}37.74 \\
\#(4.67)\end{array}$ \\
\hline Resource & 39 & $\begin{array}{c}30.21 \\
\#(4.34)\end{array}$ & 31 & $\begin{array}{c}31.06 \\
\#(3.33)\end{array}$ & 164 & $\begin{array}{c}32.42 \\
\#(3.41)\end{array}$ & 23 & $\begin{array}{c}32.35 \\
\#(3.60)\end{array}$ \\
\hline Burden & 39 & $\begin{array}{c}11.82 \\
\#(1.25)\end{array}$ & 31 & $\begin{array}{c}11.65 \\
\#(1.28)\end{array}$ & 164 & $\begin{array}{c}12.30 \\
\#(1.45)\end{array}$ & 23 & $\begin{array}{r}12.09 \\
\#(1.98)\end{array}$ \\
\hline
\end{tabular}

Note: $\# p<0.05{ }^{*} \mathrm{CH}-$ workload ${ }^{* *}$ ESFS - Basic Health Unit with Family Health Strategy ${ }^{* * *} E S F N$ - Basic Health Unit without the Family Health Strategy; IFNC-NA - Importance of Families in Nursing Care - Nurses' Attitudes.

\section{Nurses' attitudes $x$ family nursing training $x$ Basic Health Units with or without the Family Health Strategy}

Table 4 shows the attitudes of nurses who received guidance on family nursing in undergraduate school and/or training and those who did not. Those who had, present a mean in the total IFNC-NA and slightly higher dimensions $(p=0.004)$. Likewise, the attitudes of those who work in $\mathrm{BHU}$ with $\mathrm{FHS}$ are more positive than those without the FHS $(p<0.05)$.

Table 4 - Total and dimensions of "Importance of Families in Nursing Care - Nurses' Attitudes" (IFNC-NA), having received training on family nursing, Basic Health Units with and without the Family Health Strategy, Attitudes in Primary Health Care Research, São Paulo, Brazil, 2019

\begin{tabular}{|c|c|c|c|c|c|c|c|c|}
\hline \multirow[t]{2}{*}{ Variable } & \multicolumn{2}{|c|}{$\begin{array}{l}\text { FHS } \\
\text { Yes }\end{array}$} & \multicolumn{2}{|c|}{$\begin{array}{l}\text { FHS } \\
\text { No }\end{array}$} & \multicolumn{2}{|c|}{$\begin{array}{l}\text { Training } \\
\text { Yes }\end{array}$} & \multicolumn{2}{|c|}{$\begin{array}{l}\text { Training } \\
\text { No }\end{array}$} \\
\hline & $\mathbf{n}$ & $\begin{array}{c}\text { Mean } \\
\text { (SD) }\end{array}$ & $\mathbf{n}$ & $\begin{array}{c}\text { Mean } \\
\text { (SD) }\end{array}$ & $\mathbf{n}$ & $\begin{array}{l}\text { Mean } \\
\text { (SD) }\end{array}$ & $\mathbf{n}$ & $\begin{array}{c}\text { Mean } \\
\text { (SD) }\end{array}$ \\
\hline IFNC-NA & 175 & $\begin{array}{c}83.91 \\
\#(7.23)\end{array}$ & 57 & $\begin{array}{c}78.25 \\
\#(5.66)\end{array}$ & 168 & $\begin{array}{c}81.56 \\
\#(7.64)\end{array}$ & 89 & $\begin{array}{c}78.15 \\
\#(9.16)\end{array}$ \\
\hline Coping & 175 & $\begin{array}{c}38.40 \\
\#(3.13)\end{array}$ & 57 & $\begin{array}{c}36.35 \\
\#(2.52)\end{array}$ & 168 & $\begin{array}{c}38.32 \\
\#(4.45)\end{array}$ & 89 & $\begin{array}{c}37.01 \\
\#(5.19)\end{array}$ \\
\hline Resource & 175 & $\begin{array}{c}33.02 \\
\#(2.96)\end{array}$ & 57 & $\begin{array}{c}30.84 \\
\#(2.21)\end{array}$ & 168 & $\begin{array}{c}32.05 \\
\#(3.42)\end{array}$ & 89 & $\begin{array}{c}30.98 \\
\#(4.07)\end{array}$ \\
\hline Burden & 175 & $\begin{array}{c}12.18 \\
\#(1.14)\end{array}$ & 57 & $\begin{array}{c}11.05 \\
\#(0.75)\end{array}$ & 168 & $\begin{array}{c}11.18 \\
\#(1.55)\end{array}$ & 89 & $\begin{array}{c}10.16 \\
\#(2.20)\end{array}$ \\
\hline
\end{tabular}

Note: $\# p<0.05 * 27$ people did not answer whether the work unit has FHS or not; FHS - Family Health Strategy.

\section{DISCUSSION}

In Brazil, primary health care is offered, mostly, in two scenarios: Traditional BHU, with or without the Community Health Workers and $\mathrm{BHU}$ with FHS, strategies that make up the study. The main findings point out that nurses' attitudes are favorable to the involvement of families in caring for the person with MD, since the mean value of the IFNC-NA was 82.1 (SD=8.4). A close value of a recent study carried out with primary care nurses in Portugal found $85.9(\mathrm{SD}=9.6)^{(8)}$, in the dimensions: "Conversation/ coping partner family" 38.5 (SD=4.6) and "Family as a resource" 31.9 (SD=3.7); and higher in "Family: as a burden" 12.1 (SD=1.5) in both countries. It noteworthy, however, that $82.8 \%$ of the 
sample is composed of female professionals, and the authors of the original version of the IFNC-NA point out that they express, on average, attitudes of greater support and inclusion of families than the opposite gender ${ }^{(18)}$.

There was an association between nurses who received guidance on family nursing in undergraduate school and/or training, compared to those who did not, showing more positive attitudes. In Brazil, generally, family nursing education is not consolidated in undergraduate nursing curricula, and its specific approach is still conducted in a poorly structured manner ${ }^{(19)}$. Thus, it is a favorable result, but it requires other studies to assess the type of family nursing actions in the context of MD in PHC, considering, first, the theoretical and practical challenges that nurses face to implement them ${ }^{(20)}$.

Despite these considerations, another association found relates to being an ESF nurse and showing attitudes of greater support and importance to the involvement of families. This finding is based on the social commitment of the FHS, on the principles of SUS and the National Mental Health Policy (PNSM), regarding the constitution of new possibilities to assist the person/family in the community.

However, it is necessary to invest in the training of these professionals since knowledge on the importance of families in care must be necessary from undergraduate school to clinical practice $^{(12)}$. Also, nursing care to the family requires a theoretical and practical basis that supports it systematically, for example, from a systemic perspective. On the other hand, this finding contributes to improving the idea and applicability of the concept "family in care", which is currently misunderstood, since nurses still believe that families act as supervisors of their actions, and serve as "labor" for less important care ${ }^{(21)}$.

The workload varied from 30 to 44 hours/week. Nurses who work 40 hours have more positive attitudes towards the involvement of families than those who work for less or more than 40 hours. This data is in line with the 40-hour workweek established for FHS nurses who focus on their family, the possibilities of developing collaborative care with the family of the person with MD are increased. Nurses with longer professional experience have more positive and supportive attitudes towards family involvement in care, a result similar to the research conducted in central Portugal(22).

However, concerning the same items from the IFNC-NA, this study has a higher score than a Brazilian study developed five years ago with hospital pediatric care nurses, in which the scale scores were lower ${ }^{(16)}$, thus prospecting for changes in the area of family care.

The RHC/HD, where nurses perform their activities, seem to determine their attitudes slightly more positively towards family involvement in MD having obtained higher total scores on the scale in the HD Sé (Centro), Butantã (West) and Guaianazes (East). Such data are relevant, although there is an increasing trend in FHS coverage in the state of São Paulo, with an increase between 2006 and 2016(23), the model of care in traditional BHUs (without the FHS) still prevails in São Paulo, as well as some neighborhoods with low coverage, that is, with less than half of its population assisted by the FHS (24).

Health care in the city of São Paulo is set up as a network in constant movement, and in the last twenty years, Social Health Organizations (OSS) has managed a large part of primary care services, spreading their techniques, strategies, knowledge, domain and culture ${ }^{(25)}$. Still, studies on the constitution, work process, perspectives and challenges on the city's RAPS are incipient. It is also emphasized that, although the attitudes of nurses in health districts point to the inclusion or not of families of the person with MD in care, it is not possible to state that the type of OSS management in primary health services impacts these attitudes.

RHC Sé (Center) is typified by being a complex territory, with many singularities, but it still faces obstacles in accessing public services, especially health services ${ }^{(26)}$; as well as concentrating homeless in a scenario of psychoactive substances abuse. These particularities test the work of nurses in terms of having a more systemic approach, to rescue family relationships, assuming, therefore, that these aspects encourage professionals to have a broader view and ahead of other regions of the city, although this reality is common in other social settings.

$\mathrm{RHC} / \mathrm{HD}$ West, characterized by exposing good socioeconomic and health indicators in a fraction of its territory, has, especially in the Butantã region, areas of social vulnerability ${ }^{(27)}$. Despite the inability of some professionals in this micro-region to deal with cases of MD in PHC, nurses work in an interdependent and articulated way with specialized services ${ }^{(28)}$ and with a public university located in the region. Nursing teaching at this university supports the importance of families in well-structured nursing care, and supports the relevance of involvement as a primary condition for successful care. However, to achieve this goal, it adjusts the changes in beliefs and behaviors ${ }^{(29)}$, therefore, powerful influence on the most positive attitudes by nurses of this RHC.

$\mathrm{RHC} / \mathrm{HD}$ East is a peripheral space, with few resources and a densely populated region. The population recognizes health services as an important representation of the State. In the 2014-2017 municipal health plan, the goal was to arrange the line of care in $\mathrm{MD}$ in $\mathrm{PHC}^{(30)}$. It is believed that focused efforts have enabled nurses to cohesion with the community, and this approach implied a vision of families' involvement over the past two years, within the data collection period of the present study.

In the RHC North territory, political changes intervened in the constitution of RAPS, with challenges that include the diversity of territories, population contingent and decision-making based on political order at each municipal management. Although there is resistance from professionals, users and family members, there is still centrality in the asylum culture established from management contracts made by the Municipal Health Department and OSS(31).

Thus, it is assumed that there is an obstacle in the evolution of $\mathrm{MD}$ care in $\mathrm{PHC}$, which leads to less positive attitudes among nurses in this RHC. Despite the IFNC-NA scores, from the perspective of nurses from $\mathrm{RHC} / \mathrm{HD}$ Southeast, being relatively low, this region is also a field of practice for nursing students from a higher education institution, which stands out in the area of teaching family-centered care, and in the process of preparing future professionals. Thus, mobilizing nurses from primary care clinical teaching fields to transform their attitudes towards the inclusion of families in nursing care ${ }^{(32)}$.

Despite the promising results of this study, the challenges for the families' involvement in care involve overcoming nurses' mistaken ideas that families abandon their sick family member, since these professionals do not understand that family members' lack of knowledge on MD and difficulties in providing care 
is related to unpreparedness and lack of suitable support ${ }^{(33)}$. Anyway, these findings respond to national and international guidelines for the family's involvement in nursing care and the assumption by nurses, as well as the ethical and moral commitment and obligation to include them in care $^{(34)}$.

\section{Limitations of the Study}

The convenience sample does not allow generalizations about the studied population. Due to logistical issues, due to the size of the municipality's geographic spaces, it was not possible to access a larger sample, and those who participated in the study are probably the nurses most sensitized to the theme.

\section{Contributions to the Field}

The study restates the importance of positive attitudes to support nurses' decision to incorporate families and that they strengthen the community-based care proposed in the RAPS. It is the first in the country to investigate the association between the attitudes of PHC nurses about the family's participation in the care of the person with MD.

\section{CONCLUSION}

It is concluded that the nurses who work in primary care in the city of São Paulo have, mostly, a positive attitude towards the involvement of families, a relevant indicator for the integration of these in the mental-health care process. It is also pointed out that the 40-hour workweek favors greater contact with the population, and that academic training and specialization seem to be related to more positive attitudes towards families and, consequently, enhance quality in care.
Moreover, the nurses' attitudes may fall in the conception they have about the meaning of family nursing training versus acting in the Family Health Strategy, which has the family as the centrality of programmatic health action. Since the practice of MD in PHC has not yet been consolidated in the country, much less concerning the accessibility of families with MD members to care. This study provides data for decision-making within the scope of services.

The investment in the training/education of primary care nurses, in the "mental health" and "family nursing" items, enhances the inclusion of families as partners, co-responsible and facilitators in the care process. This fact is justified since the current PNSM proposal does not provide care in places of seclusion, distancing the person from their relational nucleus, since users of mental health services should preferably return to their families.

Fostering studies on family nursing, in the context of the MD person in $\mathrm{PHC}$, is relevant to produce evidence about the reinsertion of the person with this clinical condition in the social unity which is the family. As well as the acceptance of this social nucleus in non-specialized spaces, besides understanding how to build a family care practice and the determining variables for its development. In future investigations, it is considered crucial to understanding the relationship between $\mathrm{RHC} / \mathrm{HD}$, the particularities of management and the work process that improve nurses' attitudes and their connection with these families.

\section{FUNDING}

Coordenação de Aperfeiçoamento de Pessoal de Nível Superior (CAPES) Programa de Professor Visitante no Exterior-edital 9/2019 Print USP-Portugal (Bolsa). Trabalho desenvolvido no Programa de Pós-Graduação em Enfermagem- Escola de Enfermagem da Universidade de São Paulo (EEUSP).

\section{REFERENCES}

1. Fernandes CS, Gomes JAP, Martins M, Gomes BP, Gonçalves, LHT. The importance of families in nursing care: nurses' attitudes in the Hospital Environment. Rev Enferm Ref. 2015;IV(7):21-30. doi: 10.12707/RIV15007

2. Cree L, Brooks H, Berzins K, Fraser C, Lovell K, Bee P. Carers' experiences of involvement in care planning: a qualitative exploration of the facilitators and barriers to engagement with mental health services. BMC Psychiatr [Internet]. 2015 [cited 2020 Jan 20];15;(208). https:// bmcpsychiatry.biomedcentral.com/articles/10.1186/s12888-015-0590-y

3. Gaino LV, Souza, J, Cirineu, CT, Tulimosky TD. O conceito de saúde mental para profissionais de saúde: um estudo transversal e qualitativo. SMAD Rev Eletrôn Saúde Mental Álcool Drog. 2018:14(2);108-16. doi: 10.11606/issn.1806-6976.smad.2018.149449

4. Keogh B, Skärsäter I, Doyle L, Ellilä H, Jormfeldt H, Lahti M, et al. Working with families affected by mental distress: stakeholders' perceptions of mental health nurses educational needs. Issues Ment Health Nurs [Internet]. 2017[cited 2020 Jan 20];38(10):822-8. https://www.ncbi.nlm. nih.gov/pubmed/28745973

5. Cairns V, Reid G, Murray C. Family member's experience of seeking help for first-episode psychosis on behalf of a loved one: a metasynthesis of qualitative research. Early Interv Psychiatr. 2015;9(3):185-99. Available from: https://www.ncbi.nlm.nih.gov/pubmed/24958353

6. Weber CAT, Juruena, MF. Familys view on the therapeutic of a mental health partial hospitalization. RPESM. 2017;(17):25-33. doi: 10.19131/ rpesm.0180.

7. Vala J, Monteiro, MB. Psicologia Social. 9a Ed. Lisboa: Fundação Calouste Gulbenkian; 2013; pág. 188.

8. Fernandes CSNN, Nóbrega MPSS, Angelo M, Torre MI, Chaves SCS. Importance of families in care of individuals with mental disorders: nurses' atitudes. Esc Anna Nery. 2018;22(4): e20180205. doi: 10.1590/2177-9465-ean-2018-0205

9. Chiu-Yueh Hsiao, Huei-Lan Lu, Yun-Fang Tsai. Factors associated with primary family caregivers' perceptions on quality of family-centered care in mental health practice. J Nurs Scholarsh. 2019 Nov;51(6):680-8. doi: 10.1111/jnu.12526 
10. M Olasoji, P Maude, K McCauley. Not Sick Enough: Experiences of Carers of People With Mental Illness Negotiating Care for Their Relatives With Mental Health Services. J Psychiatr Ment Health Nurs. 2017;24(6):403-411. doi: 10.1111/jpm.12399

11. Ingela S, Brian K, Louise D, Heikki E, Henrika J , Mari L, et al. Advancing the knowledge, skills and attitudes of mental health nurses working with families and caregivers: a critical review of the literature. Nurse Educ Pract. 2018;32:138-46. doi: 10.1016/j.nepr.2018.07.002

12. Dirik A, Sandhu S, Giacco D, Barrett K, Bennison G, Collinson S, et al. Why involve families in acute mental healthcare? a collaborative conceptual review. BMJ Open 2017;7:e017680. doi: 10.1136/bmjopen-2017-017680

13. Blomqvist M, Ziegert K. 'Family in the waiting room': a Swedish study of nurses' conceptions of family participation in acute psychiatric inpatient settings. Mental Health Nurs. 2011;20(3). doi: 10.1111/j.1447-0349.2010.00714.x

14. Covelo BSR, Badaró-Moreira MI. Links between family and mental health services: family members' participation in care for mental distress. Interface. 2015;19(55):1133-44. doi: 10.1590/1807-57622014.0472

15. Oliveira EC, Medeiros AT, Trajano FMP, Chaves NG, Almeida SA, Almeida LR. O cuidado em saúde mental no território: concepções de profissionais da atenção básica. Esc Anna Nery. 2017;21(3):e20160040. 2017. https://doi.org/10.1590/2177-9465-ean-2017-0040

16. Angelo M, Cascaes A, Fernandes F, Cavalcante C, Costa M, Ferreira M. Attitudes regarding the importance of families in pediatric nursing care. Rev Esc Enferm USP. 2014;48(spe):74-79. doi: 10.1590/S0080-623420140000600011

17. Oliveira PCM, Fernandes HIV, Vilar AISP, Figueiredo MHJS, Ferreira MMSRS, Martinho MJCM, et al. Attitudes of nurses towards families: validation of the scale Families'Importance in Nursing Care-Nurses Attitudes. Rev Esc Enferm USP. 2011;45(6):1331-7. doi: 10.1590/S0080-62342011000600008

18. Benzein E, Johansson P, Arestedt, KF, Saveman BI. Nurses'attitudes about the importance of families in nursing care: a survey of Swedish Nurses. J Fam Nurs. 2008;14(2):162-80. doi: 10.1177/1074840708317058

19. Angelo M, Bousso RS, Rossato LM, Damião EBC, Silveira AO, Castilho AMCM, et al. Family as an analysis category and research field in nursing. Rev Esc Enferm USP. 2009;43(spe2):1337-41. doi: 10.1590/S0080-62342009000600033

20. Santos REB, Nóbrega MPSS. Mental Health in Primary Care: Annals of the Brazilian Congress of Nursing. Rev Baiana Enferm. 2017;31(4):e20134. doi: 10.18471/rbe.v31i4.20134

21. Corrêa AR, Andrade AC, Manzo BF, Couto DL, Duarte ED. The family-centered care practices in newborn unit nursing perspective. Esc Anna Nery. 2015;19(4):629-34. doi: 10.5935/1414-8145.20150084

22. Silva MANCG, Costa MASM, Silva MMFP. The Family in Primary Care: characterization of nurses attitudes. Rev Enferm Ref. 2011;3(11):19-28. doi: 10.12707/RIII13105

23. Neves RG, Flores TR, Duro SMS, Nunes BP, Tomasi E. Time trend of Family Health Strategy coverage in Brazil, its Regions and Federative Units, 2006-2016. Epidemiol Serv Saúde. 2018;27(3):e2017170. doi: 10.5123/s1679-49742018000300008

24. Malta DC, Santos MAS, Stopa SR, Vieira JEB, Melo EA, Reis AC. Family Health Strategy Coverage in Brazil, according to the National Health Survey, 2013. Ciênc Saúde Colet. 2016;21(2):327-38. doi: 10.1590/1413812320152122360

25. Baggenstss S, Donandone JC. The public health intermediated by social organizations: Arrangements and adjustments in the last two decades in Brazil. Latinoamérica Rev Estudios Latinoamericanos. 2014;(59):69-98. doi: 10.1016/S1665-8574(14)71726-0

26. Campos A. População de rua: um olhar da educação interprofissional para os não visíveis. Saude Soc. 2018;27(4):997-1003. doi: 10.1590/ s01041290 2018180908

27. Organização Pan-Americana da Saúde. Inovação e direito à saúde na cidade de São Paulo (2013-2016). Brasília, D.F. OPAS; 2017.

28. Nóbrega MPSS, Domingos AM, Silveira ASA, Santos JC. Weaving the West Psychosocial Care Network of the municipality of São Paulo. Rev Bras Enferm. 2017;70(5):965-72. doi: 10.1590/0034-7167-2016-0566

29. Cruz AC, Angelo M. Cuidado centrado na família em pediatria: redefinindo os relacionamentos. Ciên Cuid Saúde. 2012;10(4):861-5. doi: 10.4025/cienccuidsaude.v10i4.18333

30. Prefeitura de São Paulo. Plano Municipal de Saúde de São Paulo 2014-2017 [Internet]. 2017[cited 2020 Jan 20]. Available from: https://www. prefeitura.sp.gov.br/cidade/secretarias/saude/noticias/?p=187928

31. Almeida IS, Campos GWS. Analysis of the implementation of a Mental Health network in a major city. Saúde Colet. 2019;24(7):22. doi: $10.1590 / 1413-81232018247.20122017$

32. Moraes HAL, Hannes CN. Terapia comunitária: cuidado com a família na perspectiva do graduando de enfermagem. Acta Paul Enferm. 2011;24(2):165-71. doi: 10.1590/S0103-21002011000200002

33. Barros S, Nóbrega MPSS, Santos JC, Fonseca LM, Floriano LSM. Mental health in primary health care: health-disease according to health professionals. Rev Bras Enferm. 2019;72(6):1609-17. doi: 10.1590/0034-7167-2018-0743

34. Wright LM, Leahey, M. Enfermeiras e famílias: um guia para avaliação e intervenção familiar. 5th ed. São Paulo. Roca; 2012. 